\title{
Populations of granulosa cells in small follicles of the sheep ovary
}

\author{
T. Lundy, P. Smith, A. O'Connell, N. L. Hudson and K. P. McNatty* \\ Wallaceville Animal Research Centre, PO Box 40063, Upper Hutt, New Zealand
}

\begin{abstract}
The aim of this study in sheep ovaries was to determine the total number of granulosa cells in primordial follicles and at subsequent stages of growth to early antrum formation. The second aim was to examine the interrelationships among the total number of granulosa cells in the follicles, the number of granulosa cells in the section through the oocyte nucleolus, and the diameter of the oocyte. A third aim was to examine whether proliferating cell nuclear antigen labelling occurred in flattened granulosa cells in primordial follicles or was confined to follicles containing cuboidal granulosa cells. The follicles were classified using the section through the oocyte nucleolus by the configuration of granulosa cells around the oocyte as type 1 (primordial), type 1a (transitory), type 2 (primary), type 3 (small preantral), type 4 (large preantral), and type 5 (small antral). In type 1 follicles, the number of granulosa cells and oocyte diameter were highly variable in both fetal and adult ovaries. Each type of follicle was significantly different from the others (all $P<0.05$ ) with respect to oocyte diameter, number of granulosa cells in the section through the oocyte nucleolus and total number of granulosa cells. Follicles classified as type 2, 3, 4 or 5 each corresponded to two doublings of the total granulosa cell population. The relationships between oocyte diameter and the number of granulosa cells (that is, in the section through the oocyte nucleolus or total population per follicle) could all be described by the regression equation $\log _{\mathrm{e}} X=a+b \log _{\mathrm{e}} Y$ with the correlation coefficients $R$ always $>0.93$. For each pair of variables the slopes $(b)$ for each type of follicle were not different from the overall slope for all types of follicle pooled. Immunostaining for proliferating cell nuclear antigen was observed in granulosa cells in type 1 follicles, as well as in the other types of follicle. These findings indicate that 'flattened' granulosa cells in type 1 follicles express an essential nuclear protein involved in cell proliferation before assuming the cuboidal shape. Thus, when considering factors that regulate specific phases of early follicular growth, it is important to consider: (i) the follicle classification system used; (ii) the animal model studied; (iii) whether type 1 follicles are all quiescent; and (iv) the likelihood that each follicle type represents more than one doubling of the population of granulosa cells.
\end{abstract}

\section{Introduction}

The initiation of growth of primordial follicles is characterized by three main events, namely a change in the shape of granulosa cells from flattened to cuboidal, an increase in the number of granulosa cells, and enlargement of the oocyte. Thereafter, growth is characterized by the development of multiple layers of granulosa cells around the oocyte, further enlargement of the oocyte, and formation of a zona pellucida. Outside the basement membrane, an increase in the extent of the blood capillary network can be observed, together with a concentric alignment and differentiation of theca interna cells (for a review see Peters and McNatty, 1980). Throughout these developmental phases, referred to as the preantral growth phases, fluid-

${ }^{*}$ Correspondence.

Received 8 May 1998 filled spaces appear between the granulosa cells. By the time five to eight layers of granulosa cells have formed, these pockets of fluid coalesce to form an antral cavity (McNatty, 1978). Thereafter, growth to ovulation is referred to as antral follicular growth. In rats, mice, humans and cows, classification systems that include follicular formation and growth have been reported (Pedersen and Peters, 1968; Himelstein-Braw et al., 1976; Oktay et al., 1995; Braw-Tal and Yossefi, 1997). In essence, these classification systems use the section through the oocyte nucleolus and are based on the shape and configuration of granulosa cells around the oocyte, and oocyte and follicular diameter. Follicles are then classified as belonging to a type. For example, in cows, primordial follicles are referred to as type 1 follicles; these have between two and ten granulosa cells in the section through the oocyte nucleolus and an overall follicular diameter between 29 and $40 \mu \mathrm{m}$ (Braw-Tal and Yossefi, 1997). One advantage of this system over others is that it has been 
possible to compare the early stages of follicular growth across species.

At present, follicle classification systems and our interpretation of the various stages of growth are somewhat arbitrary and rely heavily on the appearance and number of granulosa cells in the section through the oocyte nucleolus. When considering factors that might regulate specific phases of early follicular growth, it would be useful to know about the total populations of granulosa cells around the oocyte and also the changes in these populations as the follicle develops through the various phases of preantral growth, as defined from the section through the oocyte nucleolus. Recently, the development of stereological techniques using the 'nucleator' or 'fractionater' principles have enabled unbiased estimates of the number of cells to be obtained from a limited number of tissue sections and even from one section (Gundersen, 1988). These procedures have been validated for determining the number of granulosa cells in ovarian follicles (Bagger et al., 1993).

A key issue in early follicular growth is determining when granulosa cells proliferation begins. For example, does proliferation begin before or after granulosa cells change from flattened to cuboidal cells? Studies in cow, rat and baboon ovaries have demonstrated that proliferating cell nuclear antigen (PCNA) immunostaining in granulosa cells is closely associated with the onset of growth of primordial follicles (Oktay et al., 1995; Wandji et al., 1996, 1997). PCNA synthesis is a prerequisite for the initiation of DNA replication (Liu et al., 1989) and is therefore a useful marker for cell proliferation. However, studies in cows, rats and baboons indicate that PCNA immunostaining is low in type 1 follicles but is present in follicles with at least one cuboidal cell (Oktay et al., 1995; Wandji et al., 1996, 1997).

The aim of this study in sheep was to determine the total number of granulosa cells in primordial follicles, and at successive stages of growth to the early antral stage. The second aim was to examine the interrelationships among the total number of granulosa cells in the follicles, the numbers of granulosa cells in the section through the oocyte nucleolus, and the diameter of the oocyte. A third aim was to examine whether PCNA labelling occurred in granulosa cells in small follicles and whether the labelling first appeared in follicles with flattened or cuboidal granulosa cells.

\section{Materials and Methods}

The recovery of ovaries was carried out in accordance with the 1987 Animal Protection (Code of Ethical Conduct) Regulations of New Zealand, after approval was granted by the Wallaceville Animal Ethics Committee at the Wallaceville Animal Research Centre.

\section{Animals and procedures}

The sheep used for these studies were of the Romney breed. Ovaries for the cell counting studies were obtained from non-pregnant ewes $(n=8)$ and female fetuses at 120 $(n=14)$ and $135(n=17)$ days after mating (term = 147 days after mating). A barbiturate overdose (sodium pentobarbitone, $20 \mathrm{ml}$ i.v. of a $500 \mathrm{mg} \mathrm{ml}^{-1}$ solution) was administered to the ewes before ovary collection. The left ovaries were fixed in Bouin's fluid and embedded in plastic (Techovit 7100; Kulzer and Co., GmBh, Werheim). The right ovaries and other tissues were used for unrelated studies. The ovaries for this study were sectioned at a thickness of 20 $\mu \mathrm{m}$ (fetal ovaries) or $30 \mu \mathrm{m}$ (adult ovaries) and all sections were stained with periodic acid-Schiff reagent (PAS).

For the immunohistochemical studies with PCNA, $5 \mu \mathrm{m}$ paraformaldehyde-fixed ovarian sections were studied from non-pregnant ewes $(n=12)$ and from female fetuses at day 135 of gestation $(n=5)$. Adjacent serial sections were stained for haematoxylin to confirm the absence of cuboidal granulosa cells in type 1 follicles. The ovaries were obtained as described earlier for the follicle studies.

For western blotting studies, gonadal tissue from a 35day-old female sheep fetus, a 2-day-old ewe lamb, an adult ewe and a 35-day-old mouse were each homogenized in $0.5 \mathrm{mmol}$ Tris buffer $\mathrm{l}^{-1}, \mathrm{pH} 7.5$, and centrifuged at $5600 \mathrm{~g}$ for $5 \mathrm{~min}$ to obtain a clear supernatant. The supernatant $(15 \mathrm{ml})$ was mixed with $5 \mathrm{ml} \mathrm{10 \%} \mathrm{(v/v)} \mathrm{SDS,} \mathrm{heated} \mathrm{for} 3 \mathrm{~min}$ at $95^{\circ} \mathrm{C}$, and cooled on ice before it was applied to the SDSpolyacrylamide gel.

\section{Classification of follicles}

Follicles were classified by the optical plane through the oocyte nucleolus to remain consistent with a classification system reported for small follicles in the bovine ovary (BrawTal and Yossefi, 1997). The follicles were classified as follows: (i) primordial follicles (type 1), one layer of flattened granulosa cells; (ii) transitory follicles (type 1a), one layer of a mixture of flattened and cuboidal granulosa cells; (iii) primary follicles (type 2), from one to less than two complete layers of cuboidal granulosa cells; (iv) small preantral follicles (type 3), from two to fewer than four complete layers of cuboidal granulosa cells; (v) large preantral follicles (type 4), from four to fewer than six complete layers of cuboidal granulosa cells and; (vi) small antral follicles (type 5), more than five layers of cuboidal granulosa cells and a fully formed antrum. Follicle and oocyte diameters were measured at right angles in the section through the oocyte nucleolus and the mean diameters were calculated. Only non-atretic follicles devoid of pyknotic granulosa cells and oocyte degeneration (for example, misshapen or shrunken in appearance) were considered in the study. Follicles classified as type 1,2,3 or 4 were recorded in the fetal ovaries and type 5 follicles were recorded in 135-day-old fetal ovaries and in adult ovaries. In an additional study of type 1 follicles, oocyte diameter and the number of granulosa cells in the section through the oocyte nucleolus from adult ovaries were noted and compared with those from fetal ovaries. The presence or absence of a zona pellucida, theca interna and an antrum was recorded for each follicle. The zona pellucida was defined as extra-membranous thickening that became obvious as a continuum surrounding the oocyte. The zona pellucida was excluded when measuring the diameter of the oocyte. The presence of the theca was recorded when there 
was an obvious concentric alignment of cells outside the granulosa cell membrane-bound region of an individual follicle. Since the outer boundary of the theca layers could not be defined precisely, the follicular diameter was measured from the basement membrane immediately outside the granulosa cells.

\section{Counting granulosa cells using the nucleator technique}

This method was performed using follicles approximately $250 \mu \mathrm{m}$ in diameter under $\mathrm{a} \times 60$ oil immersion objective lens (numerical aperture 1.4) using an Olympus BH-2 microscope with a linear depth gauge (Mitutoyo Corporation, Minato$\mathrm{ku}$, Tokyo) linked to a video camera, colour monitor, and a computer with the MicroScale TM/TC image analysis software system (Digihurst Ltd, Royston). In fetal ovaries, type 1, type 1a and type 2 follicles were selected using an automated stepping stage and an independent uniform random sampling strategy; the precise location of these follicles within the ovarian cortex was not considered. Owing to the small number of follicles at the later developmental stages (types $3-5$ ), all the sections through the ovary were used to locate these larger structures. The nucleator method used was that of Gundersen (1988) and Bagger et al. (1993). Briefly, an image of the follicle to be counted was captured with its nucleolus in the plane of focus: the nucleolus was designated as the unique sampling point of the follicle. The diameter of the oocyte and the follicle were obtained by averaging two diameters at right angles to each other. The optical plane containing the oocyte nucleolus was referred to as the 'top' of the frame. The operator then focused through the section a distance of $5 \mu \mathrm{m}$ and this was referred to as the 'bottom' of the frame. The granulosa cell nuclei in focus in the bottom of the frame were not counted. The optical plane of the section was focused stepwise back to the 'top' of the frame and all new granulosa cell nuclei that came into focus were recorded, including those at the top of the frame. Using the microscale software, the distance from each recorded granulosa cell nucleus to the oocyte nucleolus was measured. The distances were added together and the total was entered into the nucleator equation: $N_{\mathrm{nu}}=f_{2} \times 2 \times \sum d / h$, where $N_{\mathrm{nu}}=$ the estimated total number of granulosa cells in an individual follicle; and $1 / f_{2}=$ the fraction of the follicle image in which the granulosa cell nuclei were counted. In instances in which the entire follicle in two dimensions was encompassed by the basement membrane and was within the frame of the monitor, the whole observable image was used to select granulosa cells for measurement; in this case $f_{2}=1$. Conversely, if the image of the follicle exceeded the monitor screen, an independent uniform random sampling strategy was used to select fields to sample cells: for example, if every third field was used, then $f_{2}=3 ; 2=$ a constant for isotropically orientated sections; $\Sigma d=$ the total distance from the recorded granulosa cell nuclei to the nucleolus; and $h=$ the height of the optical dissector, which, in the present study, was $5 \mu \mathrm{m}$.

The principles of the nucleator technique and its application are described in detail by Gundersen (1988) and Bagger et al. (1993). Briefly, the number of granulosa cells in a preantral follicle is critically dependent on two factors, namely, the volume (size) of the cells and the volume (size) of the follicle. These two factors are taken into account in the nucleator equation (described above). By using the three-dimensional selector to obtain cells to measure, a reliable estimate of cell volume (size) is obtained: the smaller the cell volume, the greater the cell density, and thus more cells will be selected for measurement. Both follicle size and cell density are taken into account in the variable $\Sigma d / h$. In the present study, the accuracy of the nucleator estimates was verified by comparison with a three-dimensional reconstruction method using serial $20 \mu \mathrm{m}$ sections. With this method, images at $2 \mu \mathrm{m}$ intervals were projected and traced onto paper. By overlaying the tracings, the absolute number of granulosa cells in individual follicles could be determined. From 21 type 1, type 1a and type 2 follicles, the mean \pm SEM number of cells determined by the nucleator and manual procedures were $10 \pm 1$ and $11 \pm 1$, respectively. No significant difference was found between the two methods when analysed by the paired $t$ test.

The operator precision of this method was assessed by the replication of measurements of granulosa cells in follicles $(n=15)$ over 5 days and the coefficient of error was estimated to be $8 \%$.

\section{Counting granulosa cells using the fractionator technique}

The fractionator technique was performed on type 5 follicles only. These were too large at the appropriate magnification to fit entirely on the monitor to allow precise measurement from the cells to the nucleolus, as is required for the nucleator method. The equipment used was as for the nucleator method, but with the addition of a motorized stepping stage (Lang GMBH and Co., Huttenberg).

The volume of granulosa cells in individual type 5 follicles was estimated using Cavalieri's Principle in serial sections (Gundersen and Jensen, 1987). Briefly, the area of the granulosa cells was estimated in each section in which the follicle occurred by point counting. The estimated area was then multiplied by the distance between sections $(20 \mu \mathrm{m}$ in the fetal ovaries and $30 \mu \mathrm{m}$ in the adult ovaries) to give a volume of granulosa cells for each follicle. Granulosa cells were counted using a $\times 100$ oil immersion objective (numerical aperture 1.4) in a known fraction of the granulosa cell volume using an unbiased $50 \mathrm{~mm} \times 50 \mathrm{~mm}$ counting frame, and the optical dissector over a depth of $7 \mu \mathrm{m}$ using a systematic sampling regimen.

The estimated total number of granulosa cells for each follicle was calculated by multiplying the total number of granulosa cells counted in each follicle by the reciprocal of the fraction of the volume in which the granulosa cells were counted. The operator precision with this method was identical to that used for the nucleator technique and the coefficient of error was estimated to be $11 \%$.

\section{Immunohistochemistry}

The presence of PCNA was investigated using a staining kit supplied by Zymed Laboratories (San Francisco, CA). The kit uses a biotinylated PCNA monoclonal antibody (clone 
PC10) with streptaviden-peroxidase as the signal generator and diaminobenzidine as the chromagen. Briefly, the ovarian tissues were fixed in $4 \%(\mathrm{w} / \mathrm{v})$ paraformaldehyde in PBS, $\mathrm{pH}$ 7.2 , processed for histology, and embedded in paraffin wax. Paraffin wax was removed from the $5 \mu \mathrm{m}$ sections using xylene and they were rehydrated in a graded series of ethanol. Endogenous peroxidase was blocked by incubating the sections in $3 \%(\mathrm{v} / \mathrm{v})$ hydrogen peroxide in methanol for $10 \mathrm{~min}$. The tissues were then incubated for $30 \mathrm{~min}$ using the blocking solution to prevent non-specific immunostaining, followed by a 60 min incubation with the PCNA antibody and a 4 min incubation with the diaminobenzidine mixture. Replacement of antibody solution with non-immune serum removed all staining. All incubations were performed at room temperature. The sections were counterstained with haematoxylin for $4 \mathrm{~min}$. Some sections were counterstained with 0.2 mol basic fuchsin $1^{-1}$ instead of haematoxylin and diamonium nickel sulphate $\left(5 \mathrm{mg} \mathrm{ml}^{-1}\right)$ was added to the diaminobenzidine chromagen to provide an alternative visualization of PCNA localized to cells in small follicles.

\section{Western blotting}

The SDS-treated supernatants of fetal gonadal tissue, newborn lamb ovaries, mouse ovaries, ewe ovaries and the appropriate molecular weight standards in $0.5 \mathrm{mmol}$ Tris buffer $1^{-1}$, pH 7.5, were run on SDS-polyacrylamide gels (Excell Gel; SDS gradient 8-18; Pharmacia LKB Biotechnology, Uppsala) and blotted onto Immobilon-P (PVDF; Milliphore Corp., Bedford, MA). Blots were blocked for $2 \mathrm{~h}$ in $10 \%(\mathrm{w} / \mathrm{v})$ non-fat milk powder in $10 \mathrm{mmol} \mathrm{PBS} \mathrm{l}^{-1}$, $\mathrm{pH} 7.5$, with $0.5 \%(\mathrm{v} / \mathrm{v})$ Tween 20 (PBS-Tween) at room temperature and then rinsed twice with PBS-Tween. The blots were incubated with a 1:40 dilution of PCNA antibody (Zymed, San Francisco, CA) for $1 \mathrm{~h}$ at room temperature and were then each washed once for $15 \mathrm{~min}$ and then four times for $5 \mathrm{~min}$. The blots were then incubated for $1 \mathrm{~h}$ at room temperature with secondary antibody (1:500 diluted (v/v) anti-mouse $\mathrm{Ig}$, horseradish peroxidase linked whole antibody; Amersham Life Science, Amersham) followed by the washing procedure described above. An enhanced chemiluminescence kit (Renaissance ${ }^{\mathrm{TM}}$ Chemiluminescence; Dupont, Boston, MA) followed by autoradiography (exposure time $3 \mathrm{~min}$; Hyperfilm ECL; Amersham Life Science, Amersham) was used to detect immune complexes. The antibody to PCNA detected a $36 \mathrm{kDa}$ protein in all gonadal lysates.

\section{Statistical analysis}

Analysis of variance was performed on each variable (that is, oocyte diameter, number of granulosa cells in the section through the oocyte nucleolus, and total number of granulosa cells per follicle) with respect to animal, age and type of follicle after $\log _{\mathrm{c}}$ transformation. No effects were noted for any of the variables and thus the results for the 120- and 135day-old fetal ovaries were pooled. The data for the number of granulosa cells in the section through the oocyte nucleolus, the total number of granulosa cells per follicle, diameter of the oocyte, and diameter of the follicle are represented in the results as geometric means and ranges for all follicles studied. Relationships between the number of granulosa cells in the section through the oocyte nucleolus and the total number of granulosa cells per follicle, diameter of the oocyte and the number of granulosa cells in the section through the oocyte nucleolus, or diameter of the oocyte and the total number of granulosa cells per follicle were examined by regression analyses. Chi-squared analyses were performed on proportions of granulosa cells immunostained with PCNA in fetal and adult ovaries.

\section{Results}

\section{Number of granulosa cells with respect to type of follicle}

Primordial (type 1) follicles were variable with respect to the number of granulosa cells in the section through the oocyte nucleolus, the total number of granulosa cells per follicle and also with respect to oocyte diameter (Fig. 1). A concentric array of theca cells was evident in most follicles with two layers of granulosa cells and in all follicles with more than two layers. The zona pellucida was evident in most follicles with four layers of granulosa cells and in all follicles with five or more layers of cells. ANOVA revealed that each type of follicle was significantly different from the others (all $P<0.05$ ) for all parameters (that is, number of granulosa cells in the section through the oocyte nucleolus, total number of granulosa cells, follicular diameter and oocyte diameter). These data are summarized (Table 1).

\section{Relationships among number of granulosa cells in the section through the oocyte nucleolus, total number of granulosa cells per follicle and oocyte diameter}

Each of these variables (i.e. number of granulosa cells in the section through the oocyte nucleolus and total number of granulosa cells per follicle, number of granulosa cells in the section through the oocyte nucleolus and oocyte diameter, or total number of granulosa cells per follicle and oocyte diameter) could be fitted to the regression equation $\log _{\mathrm{e}}$ $X=a+b \log _{e} Y$ (Fig. 2). The regression parameters derived from this equation for all types of follicle is summarized (Table 2). For each type of follicle, the slope from the regression analysis of each pair of variables was not different from the overall slope for all types of follicle pooled.

Fig. 1. Photomicrographs of type 1 (primordial) follicles from sheep ovaries focused through the optical section containing the nucleolus. In all cases, the follicle under consideration is in the centre of the photograph. (a,b) Small diameter type 1 follicles from a fetus at 135 days of gestation. (c) Small diameter type 1 follicle from an adult ovary. (d) Medium diameter type 1 follicle from a fetus at 135 days of gestation. (e,f) Medium to large diameter follicles from adult ovaries. $(\mathrm{g}, \mathrm{h})$ Large diameter follicles from a fetus at 135 days of gestation. All photographs are at the same magnification so that the type 1 follicles shown range in diameter from 28.3 to $53.8 \mu \mathrm{m}$. Scale bar represents $20 \mu \mathrm{m}$. 

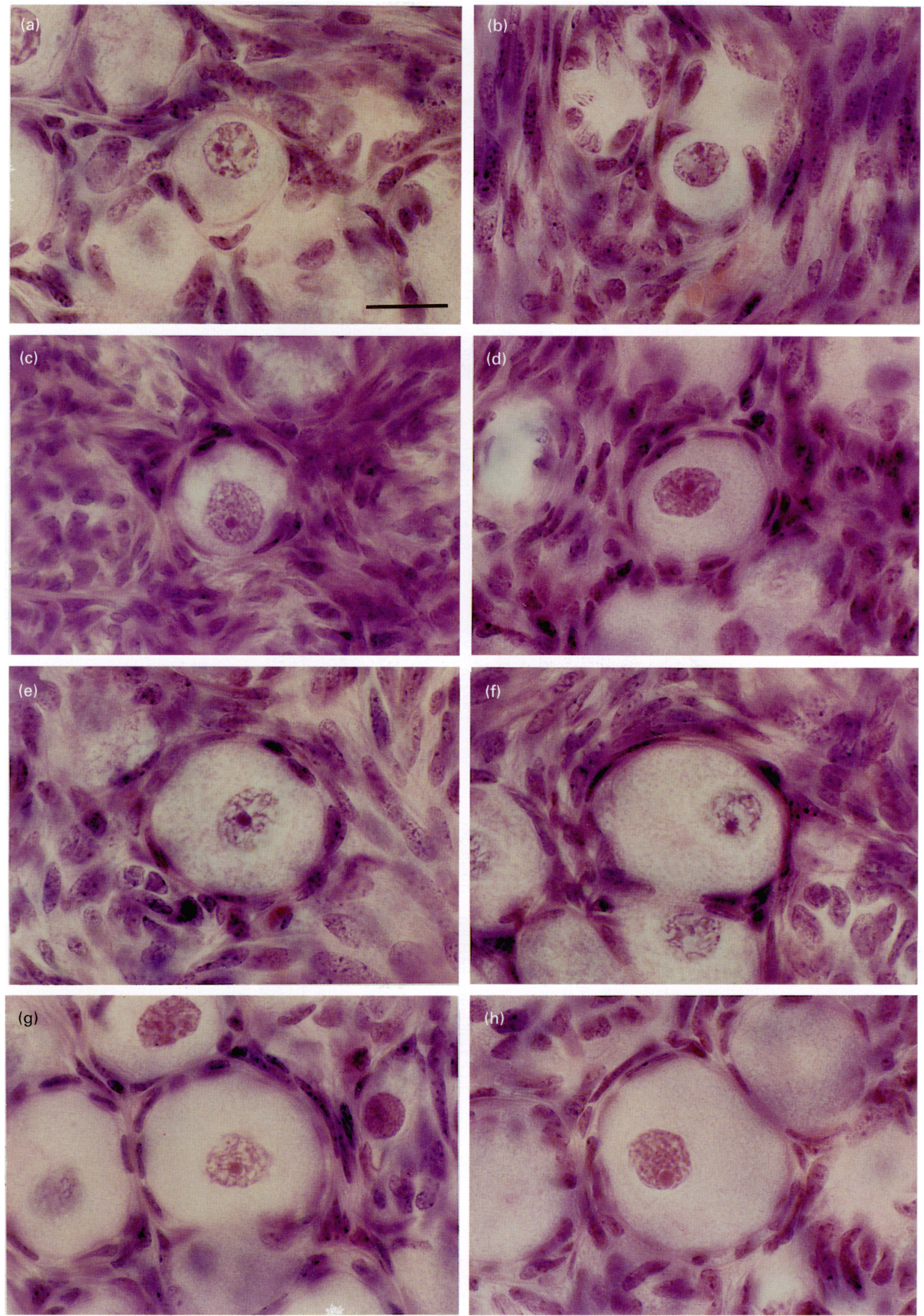


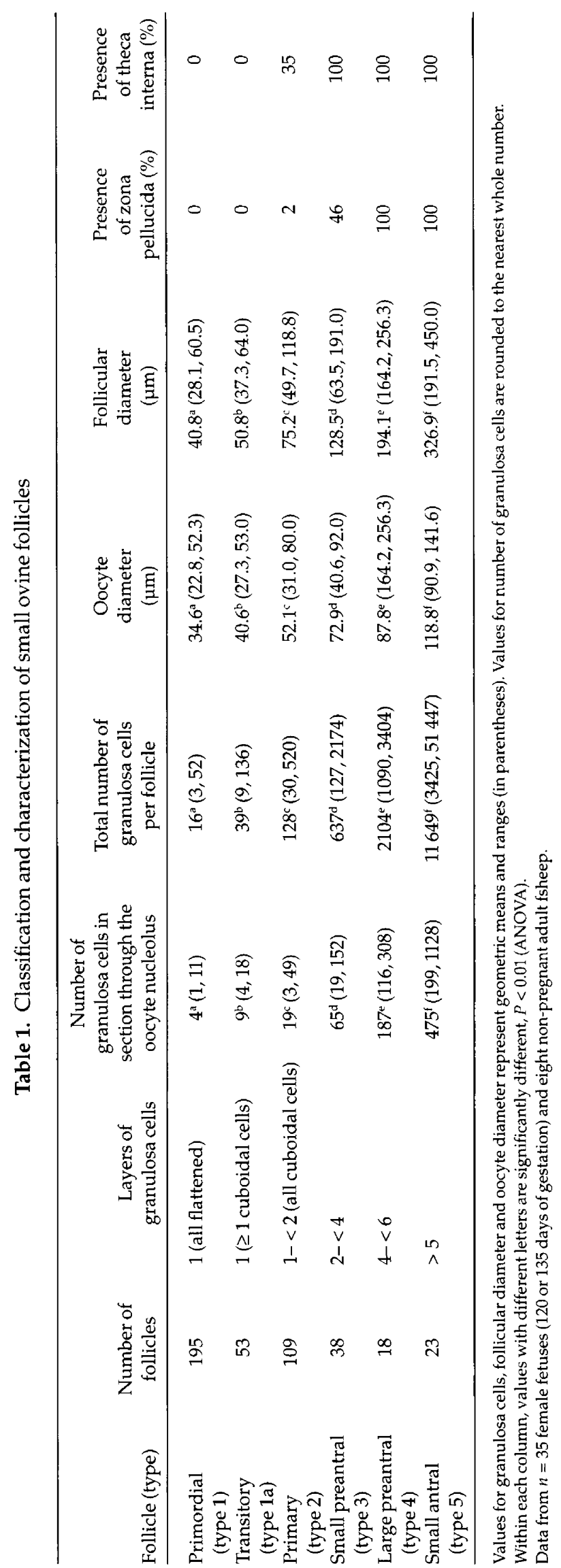



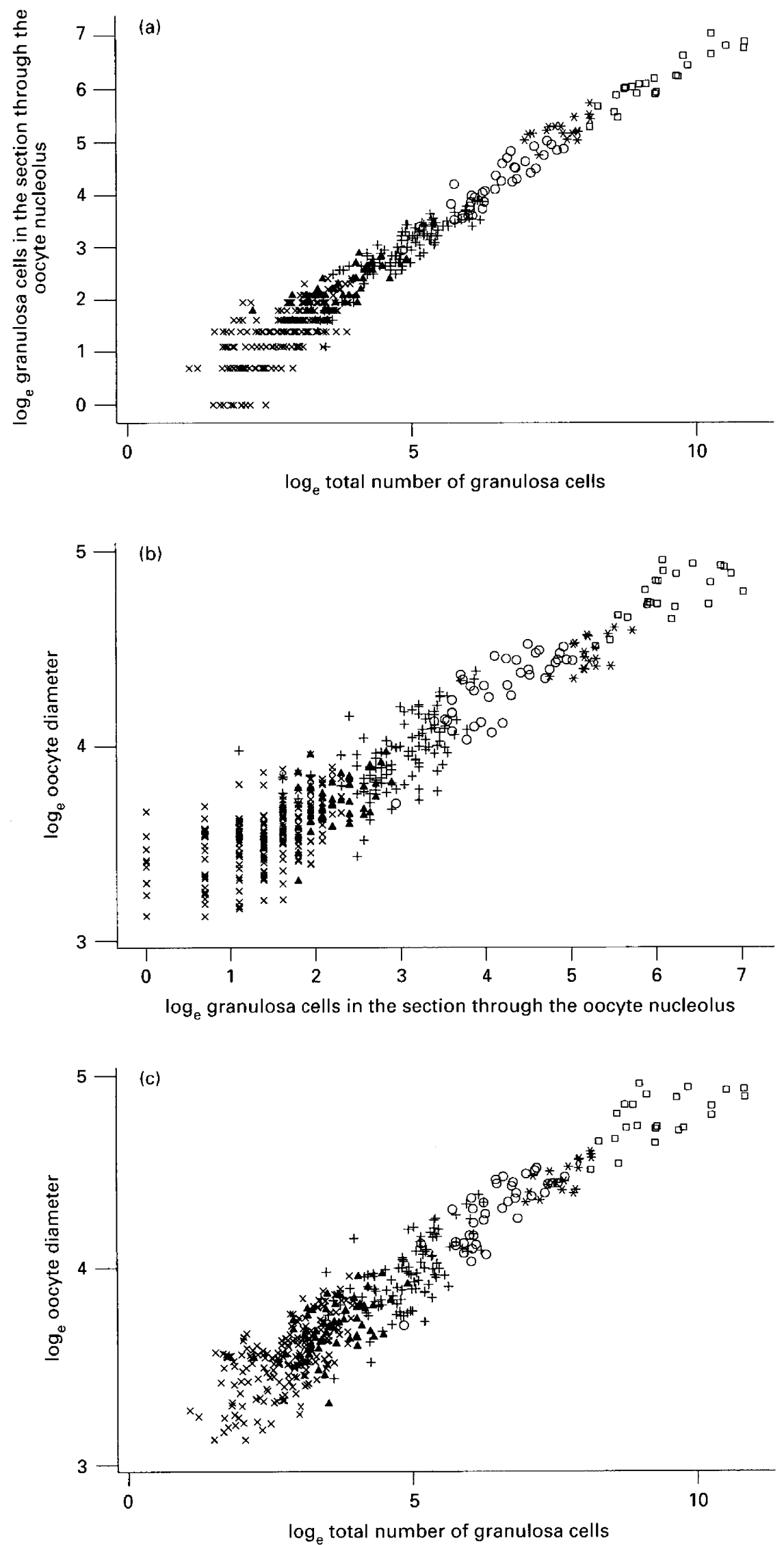

Fig. 2. For legend see page 258. 
Table 2. Parameters for regressions for all ovine ovarian follicle types pooled

\begin{tabular}{|c|c|c|c|c|c|c|}
\hline \multirow{2}{*}{\multicolumn{2}{|c|}{ Variables }} & \multicolumn{3}{|c|}{ Intercept $(a)$} & \multicolumn{2}{|c|}{ Slope $(b)$} \\
\hline & & \multirow[b]{2}{*}{ Coefficient $R$} & \multirow[b]{2}{*}{ Coefficient } & \multirow{2}{*}{$\begin{array}{l}\text { Standard } \\
\text { deviation }\end{array}$} & \multirow[b]{2}{*}{ Coefficient } & \multirow{2}{*}{$\begin{array}{l}\text { Standard } \\
\text { deviation }\end{array}$} \\
\hline$x$ & $X$ & & & & & \\
\hline $\begin{array}{l}\text { Granulosa cells in the section } \\
\text { through the oocyte nucleolus }\end{array}$ & $\begin{array}{l}\text { Total number of granulosa cells per } \\
\text { follicle }\end{array}$ & 0.975 & 0.584 & 0.037 & 0.729 & 0.008 \\
\hline Oocyte diameter & $\begin{array}{l}\text { Total number of granulosa cells per } \\
\text { follicle }\end{array}$ & 0.948 & 3.019 & 0.014 & 0.190 & 0.003 \\
\hline Oocyte diameter & $\begin{array}{l}\text { Granulosa cells in the section through } \\
\text { the oocyte nucleolus }\end{array}$ & 0.937 & 3.196 & 0.013 & 0.252 & 0.004 \\
\hline
\end{tabular}

Table 3. Characteristics of primordial (type 1) ovarian follicles in fetal and adult sheep

\begin{tabular}{lcccc}
\hline & & $\begin{array}{c}\text { Number of granulosa cells } \\
\text { in the section through the } \\
\text { oocyte nucleolus }\end{array}$ & Oocyte diameter $(\mu \mathrm{m})$ & Follicular diameter $(\mu \mathrm{m})$ \\
\hline Animal (number) & Number of follicles & $4^{\mathrm{a}}(1,11)$ & $34.6^{\mathrm{a}}(22.8,52.3)$ & $40.8^{\mathrm{a}}(28.1,60.5)$ \\
Fetal (35) & 195 & $5^{\mathrm{b}}(2,12)$ & $34.1^{\mathrm{a}}(26.3,51.7)$ & $39.3^{\mathrm{a}}(30.4,58.2)$ \\
\hline
\end{tabular}

Values are geometric means (and ranges).

Within each column, values with different letters are significantly different, $P<0.05$.

\section{Characterization of type 1 follicular parameters in adult sheep ovaries}

As the data for type 1 follicles were derived from fetal ovaries (Table 1), the question arose as to whether there is also variation in the number of granulosa cells and oocyte diameter in adult ovaries. Data for oocyte diameter, follicular diameter and number of granulosa cells in the section through the oocyte nucleolus of type 1 follicles of adult and fetal ovaries are summarized (Table 3). As was determined from the data in fetal ovaries, considerable variability was observed in the number of granulosa cells in the section through the oocyte nucleolus and in oocyte and follicular diameter (Fig. 1). ANOVA on the $\log _{e}$ transformed number of granulosa cells in the section through the oocyte nucleolus revealed a small but significant difference in the means between adult and fetal type 1 follicles. The difference in the means was attributable to the fact that adult ovaries had no type 1 follicles with one cell in the section through the oocyte nucleolus: in the adult ovaries, the smallest number of granulosa cells in the section through the oocyte nucleolus was two. When fetal follicles with only one granulosa cell in the section through the oocyte nucleolus were excluded from the analysis, no differences between adult and fetal ovaries were observed for this variable. With respect to oocyte diameter in type 1 follicles, no significant differences were observed between adult and fetal ovaries. Regression analyses of the diameter of the oocyte and the number of granulosa cells in the section through the oocyte nucleolus in type 1 follicles from adult ovaries revealed slope and intercept values that were not significantly different from type 1 follicles from fetal ovaries.

\section{Proliferating cell nuclear antigen in small follicles}

PCNA immunostaining was observed in flattened granulosa cells of type 1 follicles (that is, those containing no cuboidal granulosa cells) in both fetal (data not shown) and adult ovaries (Fig. 3). At least one granulosa cell that stained positive for PCNA was observed in $98.7 \%$ of type 1 follicles $(n=107)$ from fetal ovaries at day 135 of gestation, and in $68.2 \%$ of type 1 follicles $(n=103)$ in adult ovaries $(P<0.01$; chi-squared analysis). Moreover, in fetal and adult ovaries, $80.3 \%$ and $28.1 \%$ of granulosa cells in type 1 follicles stained positive for PCNA, respectively $(P<0.01$; chi-squared analysis). In type 1 follicles, there was no relationship between oocyte diameter and either the number or the percentage of PCNA-positive cells in both adult and fetal ovaries. The proportion of follicles or granulosa cells staining for PCNA was only determined in type 1 follicles. However, it was established that PCNA staining was widespread in both flattened and cuboidal cells in type 1a follicles and also in cuboidal granulosa cells of larger follicles (that is, types 2-5) (see Fig. 3). PCNA immunostaining in cuboidal cells varied in intensity within each follicle. In all the follicles examined, most of the oocyte nuclei stained positive for PCNA (Fig. 3).

Fig. 2. Relationships for sheep follicles classified as type $1(x)$, type 1a (ム), type $2(+)$, type $3(0)$, type $4(*)$ and type $5(\square)$ : (a) number of granulosa cells in the section through the oocyte nucleolus and total number of granulosa cells per follicle; (b) oocyte diameter and number of granulosa cells in the section through the oocyte nucleolus; and (c) oocyte diameter and total number of granulosa cells per follicle. 

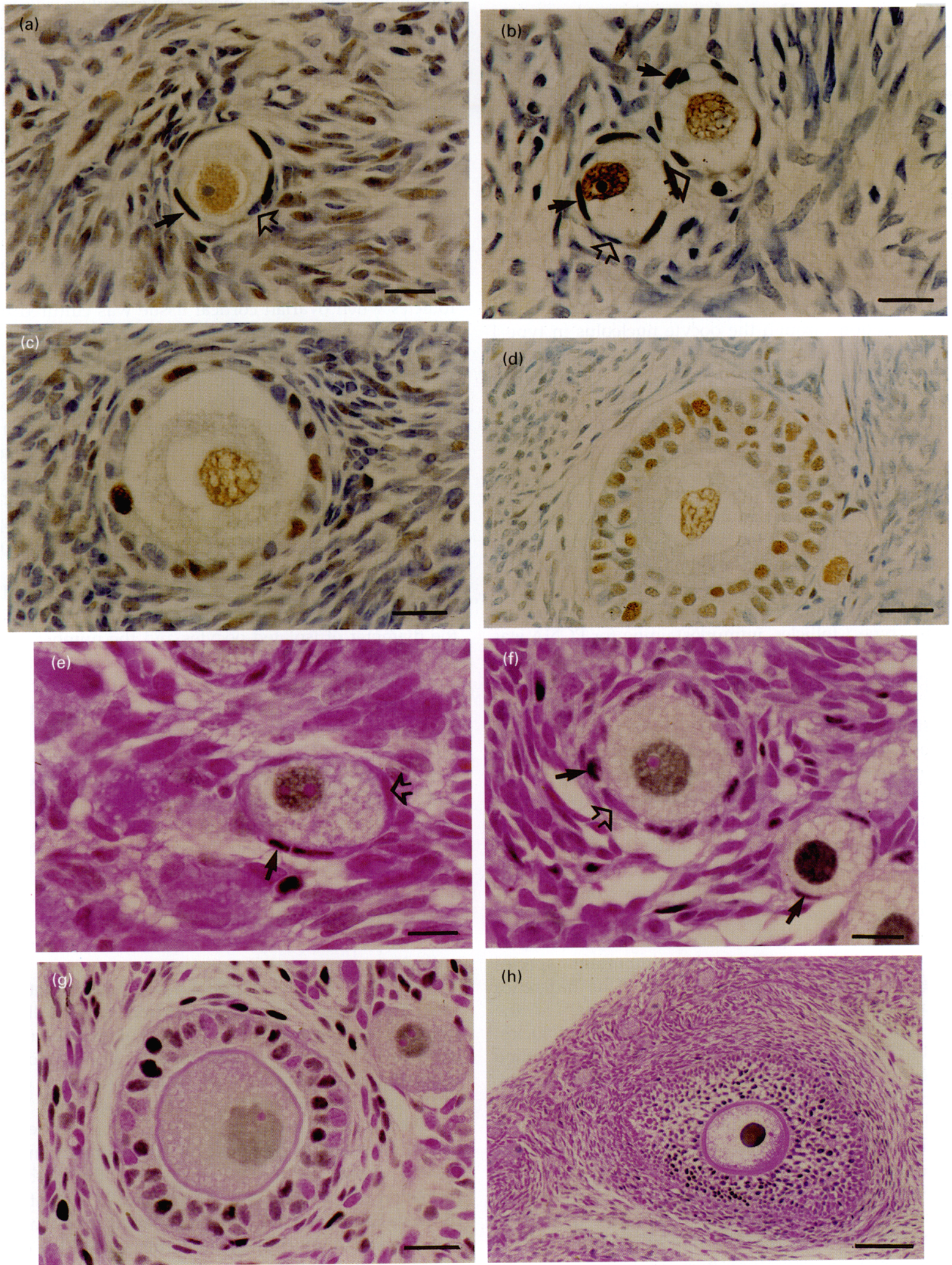

Fig. 3. Proliferating cell nuclear antigen (PCNA) immunostaining of granulosa cells and oocytes in small follicles from adult sheep ovaries. (a) Type 1, (b) types 1 and $1 \mathrm{a}$, (c) type 2 , and (d) type 3 follicles counterstained with haematoxylin. (e) Type 1, (f) type 1 and $1 \mathrm{a}$, (g) type 2, and (h) type 5 follicles counterstained with basic fuchsin. Solid arrow's indicate examples of cells labelled with PCNA; open arrows indicate cells devoid of PCNA label. Scale bars represent $(a, b, c)$ $15 \mu \mathrm{m}$, (d) $25 \mu \mathrm{m},(\mathrm{e}, \mathrm{f}, \mathrm{g}) 20 \mu \mathrm{m}$ and (h) $70 \mu \mathrm{m}$. 


\section{Discussion}

The results of this study highlight considerable variability in oocyte diameter and the number of granulosa cells in primordial follicles of sheep. These findings support the view that the small follicle pool is highly heterogeneous (Mariana, 1978; Cahill and Mauleon, 1981). The range in the number of granulosa cells recorded in the section through the oocyte nucleolus in fetal (1-12) and adult primordial follicles (2-12) was similar to those observed in cows (2-12), humans (1-14), mice (2-10), and rats (2-8) (Himelstein-Braw et al., 1976; Lintern-Moore and Moore, 1979; Gougeon and Chainy, 1987; Hirshfield, 1991; Braw-Tal and Yossefi, 1997). In sheep fetuses, the variability in the number of granulosa cells in the section through the oocyte nucleolus in type 1 follicles is also reflected in a very large range in total population of granulosa cells (that is, 3-52). Of particular interest is the association between the number of granulosa cells in the section through the oocyte nucleolus, or total population of granulosa cells, and oocyte diameter. In essence, the larger the oocyte in the type 1 follicle, the greater the number of flattened granulosa cells. This relationship was found in both fetal and adult ovaries. This is consistent with the view that primordial follicles do not represent a quiescent pool of follicles (Brambell, 1956; Cahill and Mauleon, 1981; Hirshfield and De Santi, 1995). In the present study, although mitotic figures in granulosa cells were not observed in type 1 follicles, immunostaining for PCNA was observed in a substantial proportion of these granulosa cells. Replacing PCNA antibody with non-immune serum or removal of both blocking steps indicated that the immunostaining was not due to non-specific staining or to endogenous peroxidase activity. Results of western blot analysis of protein lysates of sheep gonads with PCNA antibody were in agreement with studies in mouse ovaries (Chapman and Wolgemuth, 1994), and revealed specific binding to an approximately $36 \mathrm{kDa}$ antigen, indicating that the antibody recognized PCNA. Furthermore, using the same immunohistochemical methodology on sections from cow and rat ovaries did not result in positive immunostaining of either granulosa cells or oocytes of type 1 follicles, indicating that there are important species differences among sheep, cows and rats. This difference raises questions about the functional activities of the flattened granulosa cells of these so-called quiescent follicles. Hirschfield (1991) reported incorporation of $\left[{ }^{3} \mathrm{H}\right]$ thymidine into flattened granulosa cells in rat ovaries before they became cuboidal. Therefore, it is possible that, in sheep, PCNA-labelled flattened granulosa cells are capable of proliferating before transformation into cuboidal cells so that the follicles continue to be classified as a type 1 . The finding that a greater proportion of PCNA-labelled granulosa cells were observed in fetal compared with adult ovaries is consistent with the view that the rate of growth of small follicles is faster in immature than in mature animals (Pedersen, 1972). Nevertheless, it is noteworthy that the relationship between the number of granulosa cells in the section through the oocyte nucleolus and oocyte diameter in both fetal and adult ovaries (i.e. slopes and intercepts) was the same. This finding indicates that the underlying interactions between the oocyte and granulosa cells in type 1 follicles are similar at both ages. In individual granulosa cells of type 2 and larger follicles, the intensity of immunostaining was variable. This variation is consistent with the view that PCNA synthesis varies at different stages of the cell cycle (Liu et al., 1989) and that the mitotic activity in granulosa cells of growing follicles is asynchronous (Hirshfield, 1991).

The finding that PCNA activity was present in many oocytes, including those in type 1 follicles, is somewhat surprising given that these are in prophase of the first meiotic division. However, Oktay et al. (1995) and Wandji et al. (1996, 1997) reported similar results in rats, baboons and cows for oocytes in type 1a, type 2 and larger follicles and in type 1 follicles when ovarian cortical tissue was cultured in vitro. Moreover, Chapman and Wolgemuth (1994) reported PCNA staining in spermatogenic cells during the later stages of meiotic prophase, and proposed that PCNA may not only be involved in cell cycle activity, but also in DNA excision repair. PCNA expression is also known to be stimulated by growth factors (Jaskulski et al., 1988) and many such growth factors have been localized to oocytes in type 1 sheep follicles (McNatty et al., 1999). However, it remains to be determined whether there are causal relationships between the growth factors in the oocytes, PCNA immunostaining and oocyte growth.

It is possible that part of the variation in the follicular characteristics of primordial follicles is due to variations in the diameter of isolated oocytes and the number, type and proliferative activity of the somatic cells that become associated with the oocyte when the follicle forms (Hirshfield and De Santini, 1995). In sheep fetuses, the diameters of isolated oocytes range between 17 and $20 \mu \mathrm{m}$ (Smith et al., 1997), whereas in the present study, after formation of the follicle, oocyte diameter ranged between 23 and $52 \mu \mathrm{m}$. These results are consistent with the view that the oocyte continues to grow as the follicle forms and that growth of the oocyte may be reflected in the number of granulosa cells with which it is associated. It is proposed that a type 1 follicle could be considered as another stage in the growth continuum that begins before oocyte meiosis and ends with atresia or ovulation rather than as a resting or quiescent structure.

Follicles as the later stages of development (that is, types $1 a-5)$ are all significantly different from type 1 follicles and from one other in terms of the number of granulosa cells and diameter of the oocyte and follicle. These findings are consistent with those for other species (Arendsen de WolffExalto and Groen-Klevant, 1980; Oktay et al., 1995; Wandji et al., 1996; Braw-Tal and Yossefi, 1997) in that follicles with at least some cuboidal granulosa cells have already entered the growth phase. In the present study, the ontogeny of formation of the zona pellucida is similar to that in cows (Braw-Tal and Yossefi, 1997) but different from that in mice and humans in which the zona forms around the oocyte in primary follicles (Himelstein-Braw et al., 1976; Oakberg, 1979). In addition, in sheep, the formation of the theca appears to be similar to that in cows (Braw-Tal and Yossefi, 1997).

In addition to differences in the timing of PCNA labelling of granulosa cells in small follicles, sheep and cows also 
differ in the timing of oocyte growth. In cows, the number of granulosa cells in the section through the oocyte nucleolus increases to about 40 before a marked change in oocyte diameter is observed (Braw-Tal and Yossefi, 1997). In the present study, oocyte enlargement could not be dissociated from the number of granulosa cells at any stage of growth (types 1-5).

van Wezel and Rodgers (1996) reported that from a total of 317 type 1 follicles (type $1+$ type $1 \mathrm{a}$ ), $82.5 \%$ were type $1 \mathrm{a}$ and only $17.5 \%$ were type 1 (primordial). In contrast, in the present study, of the 248 type 1 follicles counted, only $21.4 \%$ were type $1 \mathrm{a}$ and $78.6 \%$ were type 1 . These differences may be species related, or they may be due to the fact that, in cows, there is greater variation in the shape of granulosa cells in type 1 follicles and thus it is more difficult to distinguish between flattened and cuboidal cells ( $R$. Braw-Tal, P. Smith and K. P. McNatty, unpublished).

In a study in rats, Hirshfield (1991) estimated from the number of granulosa cells in the largest cross-section that the population of granulosa cells undergoes 7-8 doublings to reach the early antral stage of follicular growth. This result is in agreement with the present study. However, it is worth noting that calculations of cell doublings based on the number of cells in the largest cross-section or in the section through the oocyte nucleolus may result in an underestimation of the true number of granulosa cell doublings that actually occurs. In the present study, despite the strong correlation between the number of granulosa cells in the section through the oocyte nucleolus and the total population of granulosa cells $(R=0.975)$, the two measurements give different results for the number of cell doublings from type 1 to type 5 of development. From the mean values for the number of granulosa cells in the section through the oocyte nucleolus, sequential development from type 1 to $1 \mathrm{a}, 2,3,4$ and 5 corresponds to one, one, two, one and one doubling of the cell population, respectively. In contrast, if the same examination is made using the total number of granulosa cells, the respective doublings for each type of follicle corresponds to one, two, two, two and two. Since many of the early growth phases are likely to be under stepwise intraovarian regulation (Huang et al., 1993; Dong et al., 1996; Matzuk et al., 1996; Guo et al., 1998), knowledge of the number of doublings of the granulosa cell population that is necessary for transit through each follicle type becomes increasingly important. In this context, the results from studies of the total population of granulosa cells indicate that follicles classified as type 2, 3, 4 or 5 each correspond to two doublings of the cell population.

In summary, the present study provides a classification system to describe the growth of small follicles in the sheep ovary. The classification system establishes some interrelationships between the number of granulosa cells around the follicle and oocyte diameter. The evidence for the sheep ovary indicates: (i) in all types of follicle, changes in the number of granulosa cells are not independent of oocyte diameter; (ii) flattened granulosa cells in type 1 follicles express PCNA before they become cuboidal; and (iii) the stages of follicular growth classified as types 2-5 each correspond to two doublings of the granulosa cell population.
The authors thank Grant Shackell, Invermay Agricultural Research Centre, for assistance with embryo transfer, Doug Jensen for assistance in managing the sheep flocks, Lillian Morrison for statistical advice, Doug Eckery for advice in preparing the manuscript, and the New Zealand Foundation for Research, Science and Technology for financial support.

\section{References}

Arendsen de Wolff-Exalto E and Groen-Klevant AC (1980) Oocyte growth in the immature rat journal of Reproduction and Fertility 59 187-192

Bagger PV, Bang L, Christiansen MD, Gundersen HJG and Mortensen L (1993) Total number of particles in a bounded region estimated directly with the nucleator: granulosa cell number in ovarian follicles American Journal of Obstetrics and Gynecology $168724-731$

Brambell FWR (1956) Ovarian changes. In Marshall's Physiology of Reproduction 3rd Edn Vol. 1 Part 1 pp 455-457 Ed. AS Parkes. Longmans Green, London

Braw-Tal R and Yossefi S (1997) Studies in vivo and in vitro on the initiation of follicle growth in the bovine ovary Journal of Reproduction and Fertility 109 165-171

Cahill LP and Mauleon P (1981) A study of the population of primordial and small follicles in the sheep Journal of Reproduction and Fertility 61 201-206

Chapman DL and Wolgemuth DJ (1994) Expression of proliferating cell nuclear antigen in the mouse germ line and surrounding somatic cells suggests both proliferation-dependent and -independent modes of function International journal of Developmental Biology 38 491-497

Dong J, Albertini DF, Nishimori K, Kumar TR, Lun N and Matzuk M (1996) Growth differentiation factor-9 is required during early ovarian folliculogenesis Nature 383 531-535

Gougeon A and Chainey GBN (1987) Morphometric studies of small follicles in ovaries of women at different ages Journal of Reproduction and Fertility $\mathbf{8 1}$ 433-442

Gundersen HJG (1988) The nucleator Journal of Microscopy 151 3-21

Gundersen HJG and Jensen EB (1987) The efficiency of systematic sampling in stereology and its prediction Journal of Microscopy $147229-263$

Guo Q, Kumar T, Woodruff T, Hudswell L, De Mayo F and Matsuk M (1998) Overexpression of mouse follistatin causes reproductive defects in transgenic mice Molecular Endocrinology 12 96-106

Himelstein-Braw R, Byskov AG, Peter H and Faber M (1976) Follicular atresia in the infant human ovary Journal of Reproduction and Fertility $\mathbf{4 6}$ $55-59$

Hirshfield AN (1991) Development of follicles in the mammalian ovary International Review of Cytology 124 43-101

Hirshfield AN and De Santi AM (1995) Patterns of ovarian cell proliferation in rats during the embryonic period and the first three weeks post partum Biology of Reproduction 53 1208-1221

Huang E, Manova K, Packer AI, Sanchez S, Bachvarova RF and Besmer P (1993) The murine steel panda mutation affects kit ligand expression and growth of early ovarian follicles Developmental Biology 157 100-109

Jaskulski D, Gatti C, Travali S, Calabretta B and Baserga R (1988) Regulation of the proliferating nuclear antigen cyclin and thymidine kinase mRNA levels by growth factors Journal of Biological Chemistry $26310175-10179$

Lintern-Moore S and Moore GP (1979) The initiation of follicle and oocyte growth in the mouse ovary Biology of Reproduction 20 773-778

Liu Y-C, Marraccino RL, Keng PC, Bambara RA, Lord EM, Chou W-G and Zain SB (1989) Requirement for proliferating cell nuclear antigen expression during stages of the Chinese hamster ovary cell cycle Biochemistry 28 2967-2974

McNatty KP (1978) Follicular fluid. In The Vertebrate Ovary pp 215-259 Ed. RE Jones. Plenum Press, New York

McNatty KP, Heath DA, Lundy T, Fidler AE, Quirke L, O'Connell A, Smith P, Groome N and Tisdall DJ (1999) Control of early ovarian follicular development Journal of Reproduction and Fertility Supplement 54 (in press)

Mariana JC (1978) Analyse biometrique de l'index de marquage des cellules folliculecises et de la taille des ovocytes des follicules primordiaux d'ovaire de rate adulte cyclique Annales de Biologie animale Biochemie Biophysique 18 1333-1342

Matzuk M, Kumar T, Shou W, Coerver K, Lau A, Behringer R and Finefold $\mathbf{M}$ (1996) Transgenic models to study the roles of inhibins and activins in reproduction, ontogenesis and development Recent Progress in Hormone Research 51 123-137 
Oakberg EF (1979) Follicular growth and atresia in the mouse In Vitro 15 41-49 Oktay K, Schenken R and Nelson JT (1995) Proliferating cell nuclear antigen marks the initiation of follicular growth in the rat Biology of Reproduction $\mathbf{5 3}$ 295-301

Pedersen T (1972) Follicle growth in the mouse ovary. In Oogenesis pp 261-276 Eds JD Biggers and AW Schuetz. University Park Press, London

Pedersen T and Peters H (1968) Proposal for a classification of oocytes and follicles in the mouse ovary Journal of Reproduction and Fertility $17555-557$

Peters H and McNatty KP (1980) The Ovary pp 10-18 Eds H Peters and KP McNatty. Granada Press, London

Smith P, O W-S, Corrigan KA, Smith T, Lundy T, Davis GH and McNatty KP
(1997) Ovarian morphology and endocrine characteristics of female sheep fetuses that are heterozygous or homozygous for the Inverdale prolificacy gene (FecX ${ }^{1}$ ) Biology of Reproduction 57 1183-1192

van Wezel IL and Rodgers RJ (1996) Morphological characterization of bovine primordial follicles and their environment in vivo. Biology of Reproduction $\mathbf{5 5}$ 1003-1011

Wandji SA, Srsen V, Voss AK, Eppig JJ and Fortune JE (1996) Initiation in vitro of growth of bovine primordial follicles Biology of Reproduction 55 942-948

Wandji SA, Srsen V, Nathanielsz PW, Eppig JJ and Fortune JE (1997) Initiation of growth of baboon primordial follicles in vitro. Human Reproduction 12 1993-2001 